BNL. 51092

\title{
MACROECONOMIC EFFECTS OF ACCELERATED IMPLEMENTATION OF RENEWABLE ENERGY TECHNOLOGIES IN THE U.S.
}

William marcuse and Paul J. Groncki

February 1980

BROOKHAVEN NATIONAL LABORATORY UPTON, NEW YORK 11973

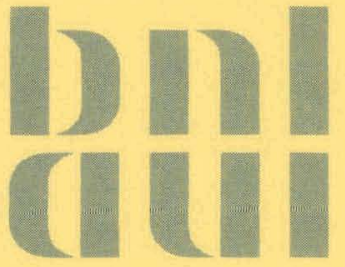




\section{DISCLAIMER}

This report was prepared as an account of work sponsored by an agency of the United States Government. Neither the United States Government nor any agency Thereof, nor any of their employees, makes any warranty, express or implied, or assumes any legal liability or responsibility for the accuracy, completeness, or usefulness of any information, apparatus, product, or process disclosed, or represents that its use would not infringe privately owned rights. Reference herein to any specific commercial product, process, or service by trade name, trademark, manufacturer, or otherwise does not necessarily constitute or imply its endorsement, recommendation, or favoring by the United States Government or any agency thereof. The views and opinions of authors expressed herein do not necessarily state or reflect those of the United States Government or any agency thereof. 


\section{DISCLAIMER}

Portions of this document may be illegible in electronic image products. Images are produced from the best available original document. 


\title{
MACROECONOMIC EFFECTS OF ACCELERATED IMPLEMENTATION OF RENEWABLE ENERGY TECHNOLOGIES IN THE U.S.S.
}

\author{
William Marcuse
}

PAUL J. GRONCKI

February 1980

ECONOMIC ANALYSIS DIVISION

\author{
NATIONAL CENTER FOR ANALYSIS OF ENERGY SYSTEMS \\ DEPARTMENT OF ENERGY AND ENVIRONMENT \\ BROOKHAVEN NATIONAL LABORATORY \\ ASSOCIATED UNIVERSITIES, INC.
}

UNDER CONTRACT NO. DE-AC02-76CH00016 WITH THE

UNITED STATES DEPARTMENT OF ENERGY

This book was prepared as an account of work sponsored by an agency of the United States Government. Neither the United States Government nor any agency thereol, nor any of their employees, makes any warranty. express or implied, or assumes any legal liability of responsibility for the eccuracy. completeness, of usetulness of any intormation, apparatus, product. of process disclosed, or commercil pros use

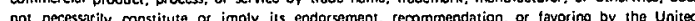
Stares Govern cont ar any arency necessarily stare or reflect those of the United States Government or any apency thereol.
UISTREGUTION OF THIS DOCUMENT IS UMLIMITEU $=-$ 
'I'his book was prepared as an account of work sponsored by an agency of the United States Government. Neither the United States Government nor any agency thereof, nor any of their employees, makes any warranty, express or im impilied, or assumes any legal liability or responsibility for the accuracy, completeness, or usefulness of any information, apparatus, product, or process disclosed, or represents that its use would not infringe privately owned rights. Reference herein to any specific commercial prod-

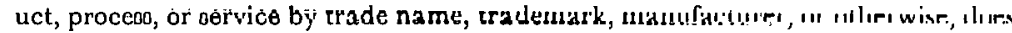
not necessarily constitute or imply its endorsement, recommendation, or favoring by the United States Government or any agency thereof. The views and opinions of authors expressed herein do not necessarily state or reflect those of the United States Govcrnment or any agcncy thereof.

Printed in the United States of America Available from

National Technical Information Service

U.S. Department of Commerce

5285 Port Royal Road

Springfield, VA 22161

Price: Printed Copy $\$ 4.00 ;$ Microfiche $\$ 3.00$ 
The original formulation of the Brookhaven energy system models was directed toward technology assessment for new and competing energy technologies. The Hudson-Jorgenson econometric model was originally formulated to identify the economic impacts of energy futures where energy use projections departed markedly from historical trends. The two models were married so that the feedback effects of energy and nonenergy demand levels and nonenergy prices generated by the economic model could be reflected in the technology and fuelmix-selection solutions of the energy model. In turn, the engineering-based energy costs, energy prices, and capital requirements for energy systems characterized in the energy model are used to override the econometric estimates based on historical data in the economic model. Recently, the coupled models have been used to address questions concerning the macroeconomic impacts of accelerating the implementation of renewable energy technologies in the United sicutes. Of particular incerest were the scenarios where 1) renewables were included which cost more than conventional alternatives now and in the future, and 2) some renewables that are initially more costly are characterized by a learning curve so that in time their costs come to equal conventional alternatives. A further analysis was done for the first case (renewables always more expensive) under conditions where 1) the incremental costs were paid by Lhe government chrough deficit financing, and 2) the incremental costs were paid by consumers. This paper will present the formulation of the analysis using the combined energy system - economic model and the results of the study. 
THIS PAGE

\section{WAS INTENTIONALLY LEFT BLANK}




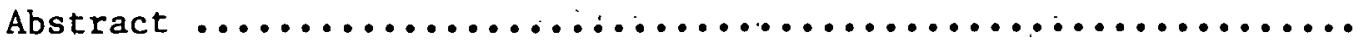

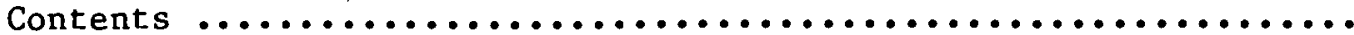

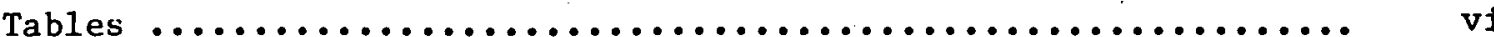

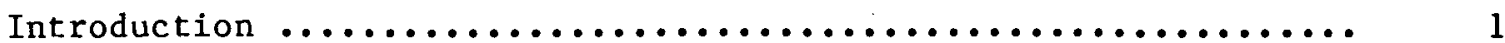

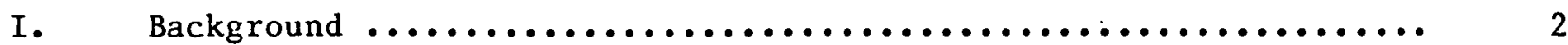

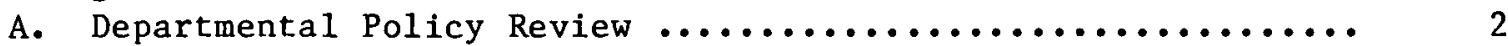

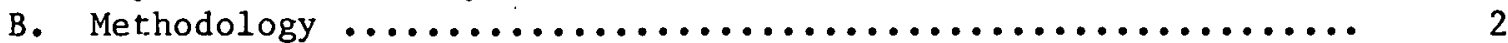

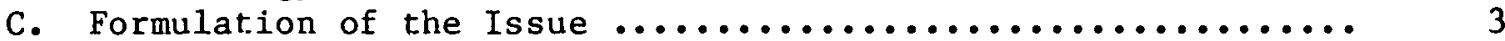

D. Study Organization ................................4

II. Approach ........................................

A. The Models ........................................

1. Econometric Model Description ..................... 5

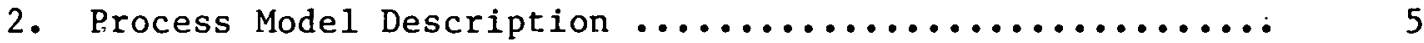

3. Input-Output Model Description ..................... 5

B. Advantages and Disadvantages of Individual Models ......... 6

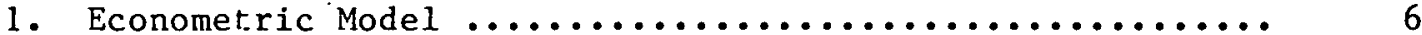

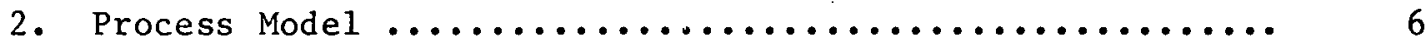

3. Input-Output Model ........................... 7

C. Benefits of Integration .........................

III. Case Specification .................................

A. Base Case ..................................... 8

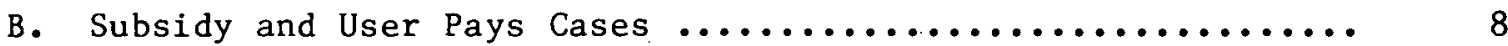

C. Competitive Case .................................. 9

IV. Economic Impacts ...................................

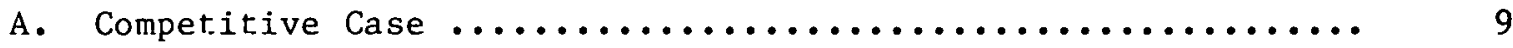

B. Subsidy Case ...................................... 12

C. User Pays Case ................................... 12

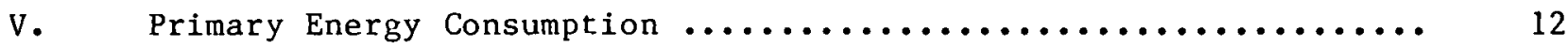

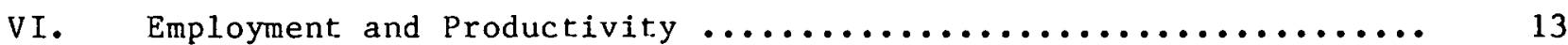

A. Aggregate Employment Effects ......................... 13

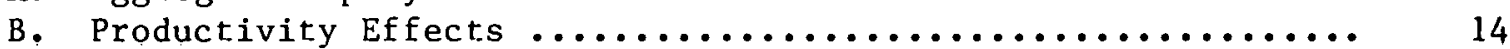

C. Disaggregated Emplóyment Effects ...................... 14

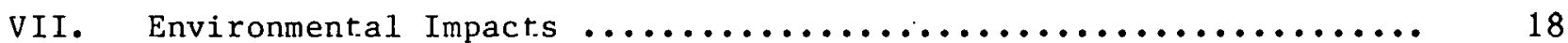

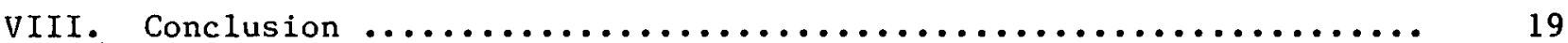

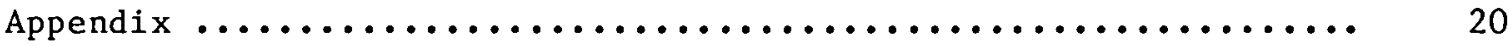

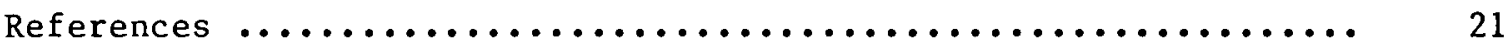




\section{TABLES}

$1 \quad$ Changes in Energy Expenditures Resulting From Base Case and Maximum Practical Solar Technology Penetrations: Year 2000 ...

Economic Impact by Sector - Subsidy and User Pays Cases Maximum Practical Implementation: Year 2000

3 Economic Impact by Sector - Competitive Case Maximum Practical Implementation: Year 2000 ............... 11

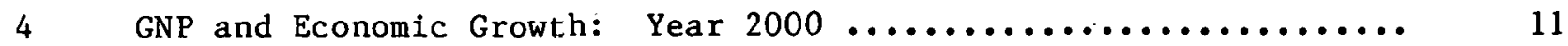

5 Primary Energy Consumption: Year $2000 \ldots \ldots \ldots \ldots \ldots \ldots \ldots \ldots \ldots \ldots$

6 Employment and Productivity: Year $2000 \ldots \ldots \ldots \ldots \ldots \ldots \ldots \ldots \ldots \ldots$

7 Sectoral Employment. Changes: Year $2000 \ldots \ldots \ldots \ldots \ldots \ldots \ldots \ldots \ldots \ldots \ldots$

8 Comparison of the Occupational Structure of Total Industrial Employment - Year 2000 Cases ............. 17

9 Comparison of the Industrial Structure of lotal Industrial Employment - Year 2000 Cases .................. 18

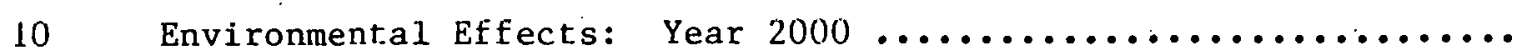




\section{INTRODUCTION}

This paper presents the results of a study of energy/economy interactions, which were generated by the concurrent solution of three complex models. The study is discussed in the context of the limitations and constraints imposed on the analysis by the decision-making environment. Thus, the operational process of defining and clarifying the needs of decision makers is explicitly presented.

Descriptions of the analytical models, the nature and current status of the linkages between the models, and plans for future development are documented elsewhere (Groncki and Marcuse, 1979). The underlying approach is that of a hierarchical, decomposed structure with the outputs of one model fed as inputs to the others. The methodologies for the interfaces have evolved over time and the transformations have become routine. The analyst still oversees the interfaces to be sure that the models behave reasonably during the solution routine and to reduce the risk of surprise outcomes.

Most systems analysis reports are on work performed at universities or research centers and are complete in the sense that all possible pathways and outcomes are examined and discussed. In contrast, much work performed directly for decision makers and that enters into the decision process is not reported at al1. When it is documented, it is often presented as completely finished even though much of the polishing and detailed analysis was done after the fact. This paper presents a policy analysis that was performed under conditions that are, unfortunately, all too typical. Not all of the analytical questions raised during the study were completely addressed; the "optimal" formulation of the problem was discarded in favor of a "timely" one; and several shortcuts were empioyed to provide the decision maker with access to the best available information when he needed it, instead of fully refined information when it was no longer useful. This paper presents an unembellished account of a study that was executed under severe constraints.

The study was commissioned by Bert Mason and Greg Ferris of the Solar Energy Research Institute (SERI) and in response to a request from the office of Solar Planning and Technology Transfer, U.S. Department of Energy (DOE). Mason played a seminal role in translating the concerns of the office into the formulation of the analysis. The technological data were provided by Ferris. The study was executed by a team consisting of Richard J. Goettle IV, Paul J. Groncki, and Joan Lukachinski of Brookhaven National Laboratory; and Edward A. Hudson and David C. O'Conner of Dale W. Jorgenson Associates. The analysis was prepared for DOE to be used in testimony before the United States Congress in support of their program. The original presentation to the sponsor was in the form of an oral report accompanied by briefing charts. The only documentation to date has been an unpublished research memorandum. 


\section{BACKGROUND}

\section{A. Departmental Policy Review}

In the fall and winter of 1978, the United States Department of Energy (DOE) launched a comprehensive departmental policy review (DPR) of solar energy options. The DPR recommended a solar energy "maximum practical" implementation by the year 2000, with solar energy sources providing about 14 quadrillion Btu (quads) of primary energy (fossil fuel equivalents). This figure is just below $13 \%$ of total primary energy projections for the year 2000 . The DPR base case (which assumes no special solar initiatives above those already legislated plus the effect of higher energy prices) projects a solar sector supplying 6 quads of primary energy in 2000 .

In February 1979, the Office of the Assistant Secretary for Energy Techno1ogy in DOE asked the Solar Energy Research Institute (SERI) to assess the employment implications of the DPR scenarios. It is widely believed that solar and conservation alternatives to fossil fuels are job creating, and thus, the possible effects of energy policies on employment are of primary concern to Congressional staffs. As discussed below, this question was reformulated.

\section{B. Methodology}

SERI identified the combined Brookhaven National Laboratory (BNL)/Dale W. Jorgenson Associates (DJA) linked energy/economy model as a candidate methodology. Upon discovering that both models were linked to the BNL version of the BNL/Iniversity of Illinois input-output model allowing the analysis of detailed sectoral effects, SERI commissioned BNL and DJA to perform the analysis. The methodology, developed to analyze the effect of alternative energy policies and technologies on the U.S. energy and economic systems, involves the integration of three different models (Groncki and Marcuse, 1979). A macroeconomic growth and interindustry model (econometric in nature) is used to estimate the aggregate energy/economy interactions and the long-run path of the economy (Jorgenson and Hudson, 1974). A linear programing process model is used to estimate the least cost method of meeting specified energy service demands and captures the substitution possibilities within the energy system (Kydes, 1978; Kydes and Rabinowitz, 1979). A disaggregate input-output model is used to assess the impacts of the aggregate energy/economy interactions on detailed industrial sectors (Tessmer et al., 1975; Fraser, 1978).

The integration of these models takes place at two levels. The first integration is between the econometric model and the process model. Ihe second uses the solution to the first coupling to provide the final demand and energy sector detail that drives the input-output morel.

The process model (BESOM) allocates energy supply so as to satisfy a set of demands for energy services. The level and structure of the energy demands are set such that they incorporate the economic conditions reflected in the energy policy measures and generated by the econometric model (LITM). The model coupling operates through several stages. Initially, average energy supply prices are calculated in BESOM and then related to price elasticities of demand to yield estimates of primary energy consumption and corresponding energy service 
demand levels (the elasticities summarize the results from previous runs of the BESOM/LITM system). BESOM is then solved, subject to providing these quantities of energy services. The solution values of energy prices, capital requirements, quantities, imports, and levels of new energy technologies from BESOM are entered into LITM which yields specific estimates of the level and composition of production and spending throughout the economy. Economic sector outputs, and the energy input per unit of output, are mapped into a set of demands for energy services, specified in British thermal units (Btu). Next, these energy service demands are adjusted to incorporate the effects of any efficiency improvements in energy end-use devices. At this point, the energy demand vector reflects changes in energy prices, the level and composition of spending in the economy, energy and nonenergy input substitutions in production, and end-use device efficiencies. These energy demands are inserted in BESOM and, along with the policy-specific price assumptions, yield a second-round simulation of the configuration of the energy system. The iteration procedure then continues until consistency between the energy and economic systems in the two models is attained (Behling et al., 1977; Lukachinski et al., 1979).

Once a consistent BESOM/LITM solution is achieved, the input-output model is run. The aggregated nonenergy final demands from LITM are used as control to tals for the nonenergy final demands in the input-output model. The energy final demands in the form of energy services are provided by BESOM. In addition, the technical coefficients representing the energy supply to energy product conversions are derived from the BESOM/LITM solution. This allows for the incorporation of energy supply substitutions resulting from specific policies in the input-output model. At this time, the nonenergy coefficients are fixed and are not policy dependent (Groncki, 1978). The input-output model is then solved yielding the detailed output requirements of the economy (Fraser, 1978).

\section{Formulation of the Issue}

The original request was to examine the employment-generating effects of the DPR "maximum practical" solar implementation. The DPR scenario depicts the penetration of solar technologies over the next twenty-five years so that the impact on the labor force occurs gradually during that period. Since the forces, affecting the economy-wide demand and supply of labor far exceed the impact of a gradual substitution of solar for conventional energy technologies, it is obvious that the direct and indirect impacts of the DPR scenario might be to change the occupational structure, the skill mix, and, to a small degree, the productiv ity of the labor forre. The level of employment will be a tunction of the supply and demand for labor and a market-clearing wage rate. This does not mean that substantial unemployment may not exist at any given moment during the period caused by either a non-market clearing wage rate that is slow to respond to the excess supply or a pool of functional unemployables (structurally unemployed). Government policies designed to offset these types of unemployment must meet several tests: the expenditure stream must be timed such that it has a large and quick impact, the occupatiunal $\mathrm{mix}$ of those to be employed should conform to the mix of currently unemployed and the policy alternative must prove preferable to other short-run employment generallng programs. 
Although the solar alternatives may generate an increase in demand for certain types of labor, the supply of this labor can only come from the labor pool available for all economic activity. Since a general equilibrium model incorporates labor supply as well as demand, wage rates will adjust to clear the market. Hence, no excess labor is available and the additional demand must be met by diverting labor from other activities, and thus changing the mix of occupational skills. Of course, if the DPR technologies increase labor productivity, wages will rise and additional labor will be forthcoming. If productivity is decreased, the reverse will happen. Only if long-run equilibrium is achieved with a chronic excess supply of labor w111 labor-absorbing technologies increase employment. However, under these circumstances policy makers could turn to any other labor-intensive activity to absorb the excess labor. Excess labor supply may also result from structural unemployment, but. there is little reason to believe that solar technologies will eliminate this pool more effectively than other measures aimed directly at the structural problem.

The sponsors were alerted to the faot that j.t is not meaningful to seek solutions to short-run problems through long-run policles nor to analyze shortrun responses with long-run policy models. The sponsor accepted the suggestion that two important labor-related issues should be considered: (1) the changes that are likely to occur in the sectoral and occupational seructures of employment resulting from the DPR scenario; (2) the change in labor productivity and consequently in real wages assoclated with the enhanced solar scenario.

\section{Study Organization}

The study was commissioned in February to support testimony by the DOE staff before Congressional hearings which were to begin in April. This time frame was too tight to permit completion of the necessary contractual arrangements, generate a fully calibrated base case, incorporate the SERI solar technologies and data in the modeling structure, carcy out the itcrative solutinn procedure between BNL and DJA, and report the outcomes. Moreover, the funding levels were inadequate and insufficient staff time was available for the analysis within this narrow window. The timeliness and importance of the questions made the analysis of intercst to all parties. However, a calibrated base case existed for a scenario that approximated the price paths of the DPR base scenario, so that, with appropriate modifications, it could be employed in the study. Although this shortcut introduced some anomalies into the analysis, the results are qualitatively meaningful.

It would be very valiuble to compare the outcome of a similar study performed with adequate funding and analysis time. An old lesson relearned during this exercise is that decision makers requesting information provided hy large complex modeling structures should commit some resources on a continuing basis to refine and improve the models and data. This will assure quick turn around, better models, and timely information. Even the best models are not fully effective when they are intermittently employed by individuals whose primary support lies elsewhere. 


\section{APPROACH}

A. The Models

1. Econometric Model Description. The econometric model is the Dale $W$. Jorgenson Associates (DJA) Long-term Interindustry Transactions Model (LITM). The DJA model simulates the structure and growth of the U.S. economy. Economic activity is estimated on a sectoral basis: six energy and four nonenergy sectors. Explicitly modeled are the dynamic and interdependent structures of prices, inputs, and final demands. The sectors are brought into consistency through a flexible coefficient interindustry representation of sectoral production. The production capacity of the economy over time is modeled by the explicit incorporation of productivity, investment, and labor supply. The emphasis is on the energy system and its role in the economy, in relation to both production and consumption. The model provides a consistent framework for analyzing the effects of economic changes on the energy system and of energy changes on the structure and growth of the U.S. economy. The interrelationships are estimated econometrically on a 1947 to 1972 data base (Jorgenson and Hudson, 1974 ).

2. Process Mode1 Description. BESOM is a linear programing model of the U.S. energy system in which the total annualized system cost of satisfying a given set of national energy product demands is minimized. Given both a set of energy requirements defined by end use (e.g., motive power, space heat, electric fower) and a set of available energy resources and conversion technology capacities, the model determines the minimum cost allocation of energy supplies to meet energy demands. BESOM includes all alternative energy resources, both electric and nonelectric demands, and the full feasible range of interfuel substitutability.

BESOM is formulated as a classical transportation problem. It determines the optimal routing of a set of intermediate energy products from a set of $n$ resource supply nodes to m energy service demand nodes. A unit of energy passing over each of the possible $n \times m$ paths has associated with it a cost and set of environmental impacts. This representation is modified by the inclusion of conversion efficiency coefficients in the supply and demand constraints, and is augmented by additional equations reflecting the specific environmental features and technical relationships of the energy system. Incorporation of plant capacity constraints, resource supply curves, demand specifications, and constraints on technology penetration rates complete the detailed characterization of the national energy system and allow for a quantitative evaluation of energy technologies and policies within a systems framework (Cherniavsky, 1974).

3. Input-Output Model Description. Several characteristics of the BNL input-output model differentiate it from conventional interindustry input-output models. First, the BNL model is composed of energy and nonenergy sectors with the output of the energy sectors expressed in physical units (Btu), instead of the conventional constant or current dollar values. (The nonenergy sector output is expressed in constant dollars.) Second, outputs of the energy supply and 
conversion sectors are distributed to energy service sectors, not directly to consuming sectors. The supply sectors convert and distribute raw fuels to sectors producing traditional energy forms (e.g., electricity and refined petroleum products), but they allow for nontraditional patterns (e.g., refined petroleum products from coal). The outputs of the se energy supply/conversion sectors are then distributed to dummy energy product or service sectors.

This structure allows the specification of transactions in terms of fuels and end uses. The dummy energy product sectors define end-use demands for energy that exhibit a limited degree of substitutability (motive power, petrochemical feedstocks, coke, process heat, water heat, space heat, air conditioning, and electric power).

The interindustry structure of an input-output transactions matrix provides a significant degree of disaggregation, which permits detailed sectoral analysis within the context of the national economy. The input-output accounting system is particularly useful in bridging the gap between the microstructure of each sector and the aggregates such as GNP and personal consumption expenditures (Tessmer et al., 1975; Fraser, 1978).

\section{B. Advantages and Disadvantages of Individual Models}

1. Econometric Model. The original formulation of LITM was undertaken for the Ford Energy Policy Project. At that time, before the 1973 oil embargo, the model was used to show the long-run effects on the U.S. economy of two energyconserving futures, a technical fix scenario and a zero economic growth scenario. The model projected large reductions in energy use with relatively much smailer reductions in economic output. This result was counter to the 1973 conventional wisdom, and the model was challenged on its lack of technological content. Like all econometric models, it represented technological change as an implicit elasticity, but did not specifically identify or describe the technologies. A strength of the LITM model is that the composicion of flinal demand and the factor mix for each energy and nonenergy sector are functions of factor prices. Unlike all previous and most subsequent models, this price-responsive representation of input-output relationships is more realistic than projections of constant input-output relationships (Charles River. Associates, 1977; Fnergy Policy Project, 1974).

2. Process Model. Energy demands for the process models are generated by projecting the level of energy services. The model solutions respond to higher energy prices by introducing more energy-efficient, higher capital-cost technologles and shifting the fuel mix to incorporate relatively lower priced fuels, but the service demands remain unchanged. Hence, reallstic demand responses are only partially captured and the implicit energy demand elasticities are too small. An additional weakness of piucess oudels is that the oolutione flip flop so that closely competing technologies are either totally chosen or totally rejected. On the positive side, the process models present each technology in engineering detail, which is useful in integrating the contributions of economists and engineers. Sensitivity analyses of uncertain costs or constraints are easily performed with the available software packages. The normative model solutions can be used to Indlcale socially beneficial policy initiatives where 
market imperfections would tend to interfere with the adoption of efficient technology options. The solutions generate shadow prices whose magnitudes are extremely useful as a sensitivity measure (Charles River Associates, 1977).

3. Input-Output Model. Typical input-output models incorporate historical base year coefficients. These fixed coefficients do not reflect the changing composition of the sectoral output due to changing relative prices or the scale effect of different output levels as capltal equipment of differing vintages is phased in or out. In addition, the tables are dated since a half a decade or more usually passes between the collection of the data and subsequent publication of the coefficients. Although schemes exist to project coefficients, projections still suffer from the scale, vintage, and sector mix weaknesses. Inputoutput models do not include coefficients for new technologies, nor can the coefficients change in response to relative price changes.

The Brookhaven-Illinois version of the Department of Commerce 1967 input-output tables was developed to ameliorate some of these problems for energy studies. First, new technologies were introduced by adding appropriate rows and columns. Second, intermediate and final energy demands are respecified in terms of energy services, and dummy sectors are added to convert fuels to energy services. Third, the energy supply and energy service sectors are defined in physical units. This permits direct linkage with the energy process model and provides variable energy coefficients, determined by the solution of the process model. Finally, the nonenergy coefficlents are projected for future years. A consistent accounting framework is provided by the input-output approaches, which can be used to trace the system wide effects of policy initiatives or changes in final demand in a comprehensive and systematic manner (Just et a1., 1975; Charles River Associates, 1977; Fraser, 1978).

\section{Benefits of Integration}

The weaknesses associated with each of the above models were recognized by the model builders. In 1973, an effort was begun at Brookhaven to link the energy sectors of the Illinois input-output model to the Brookhaven process model. At the same time the MITRE Corporation was asked by Brookhaven to provide input-output coefficients for advanced energy technologies. This coupling, completed in 1975, spread out across the ninety nonenergy sector $I-0$ model, the output, employment, balance of payment, and capital requirement effects of various energy policies and advanced technology options. To a large extent this model could be used to answer the net energy questions that were being raised at the time.

Because of criticism of the Ford Policy Model for its lack of technological detail and of the process model for its lack of price elasticities and energyeconomy interactions, a program of model linkage was initiated in 1975 . Energy demands for the process model were derived from the econometric model solution. The econometric model was constrained by the technologically determined prices, capital requirements and fuel mix from the process model. Still later, it was used to provide control totals for the nonenergy sectors of the already linked process $/ 1-U$ models. Work is currently under way to reflect in the $I-0$ model the variable coefficients from the econometric model, including adjustment of the labor and capital value-added coefficients (Gronck1, 1978). 
These integrating activities have succeeded in strengthening each model by directly supplementing its weaknesses with the strength of a complementary model. The weakness associated with the national dimension of a U.S. energy model remains, although the solution can be broken into a regional version of the process model. Finally, neither the supply sectors nor the international impacts are fully modeled and their treatment is exogenous to the model structure (Hoffman and Jorgenson, 1977).

\section{CASE SPECIFICATION}

The solar penetrations for the base case (there is no further encouragement of solar beyond that legislated at the end of 1978) and the DPR "maximum practical" cases were given. (See Appendix.) The 11fe-cycle costs for solar techno1ogies, supplied by The Solar Energy Research Institute, were higher than the iifecycle costs of conventional technologies, even with rising fuel prices. It was assumed that the introduction of the higher cost solar technologies would be encouraged by a government subsidy or that consumers might voluntarily decide to pay the higher costs. On the basis of these assumptions, two cases were analyzed: "subsidy" and "user pays." A third scenario was chosen which is characterized by decreasing costs of solar technologies to levels making them competitive with conventional technologies. This analysis case is labeled

"competitive."

\section{A. Base Case}

The base case was a business-as-usual, low solar market penetration case. For a completely calibrated solution, 1t would be necessary to start by fixing the solar implementation and the DPR energy price scenario and constraints. The models would then be run iteratively until all three converged. This calibration takes time and effort, and does not easily permit reference case input changes after a solution is reached. Because of the uncertainty concerning the reference case specification and the need to meet the tight time deadline, it was considered advisable to use an approximation.

The new base case was generated from an existing library case by inserting into the process model the SERI solar technologies in place of those in the archival run. The DPR base line penetrations were entered as solution constraints, and the solution obtained was a reasonable approximation to the original one. The resource and time constraints precluded a completely integrated solution including the DJA model. The model outcomes should be used to compare the differences in solution quantities between the base case and the "subsidy," "user pays," and "competitive" cases and not the absolute quantities associated with the base case solution.

B. Subsidy and User Pays Cases

For both these cases delivered energy from conventional sources is displaced by solar alternatives. Consequently, the total resource cost of conventional 
sources would be lower. However, total energy costs rise because the decrease in conventional energy costs shown in Table 1 is exceeded by the increase in solar energy costs. The solar costs are incurred for additional capital and labor services as well as increased purchases from the nonenergy sectors. The net effects of these cost changes are shown for the DPR "maximum practical" penetrations in Table 2. Both the subsidy and user pays cases are modeled by assuming the 24 billion dollar increase in cost is removed from consumers' incomes via a tax. In the subsidy case it is returned to them to spend in the nonenergy sectors, whereas for the user pays case it is not returned.

\section{Competitive Case}

The assumption underlying the competitive case is that solar costs fall to a level competitive with conventional energy costs. To simulate this case, the 24 billion dollar difference between the "maximum practical" and base cases is reduced to zero. Since solar technology breakthroughs are most likely to reduce capital costs, this differential is deducted totally from capital services. The competitive case cost adjustments by sector are shown in Table 3 . By specifying all three analysis cases in this aggregated manner, the scenario changes are largely confined to the macroeconomic model while the physical technology representation in the energy models remains unchanged.

\section{ECONOMIC IMPACTS}

Table 4 presents the values for GNP and its components for the base case and for the three DPR "maximum practical" cases. It is clear that if the cost of solar technology does not exceed that of conventional energy sources, economic activity is not affected. On the other hand if solar energy is more expensive, future economic output and the rate of growth of the economy are reduced. Although this reduction seems small, the cumulative effect of even a small annual percentage change can become quite large over a period of decades.

\section{A. Competitive Case}

The competitive case shows no change from the base case in GNP or its components. This is expected if the resource costs of the competitive case are nn greater than those in the base case. The calculated values, carried out to more than three significant figures, show a slight decline in GNP, almost all of it in consumption. This is consistent with the necessity to free up more output in the early years for capital which characterizes the case with more solar penetration. Thus the time phasing of capital expenditures in the base case compared to the competitive case leads to more investment for the competitive solar options in the first few decades and greater consumption later. 
Table 1

Changes in Energy Expenditures Resulting From Base Case and Maximum Practical Solar Technology Penetrations: Year 2000

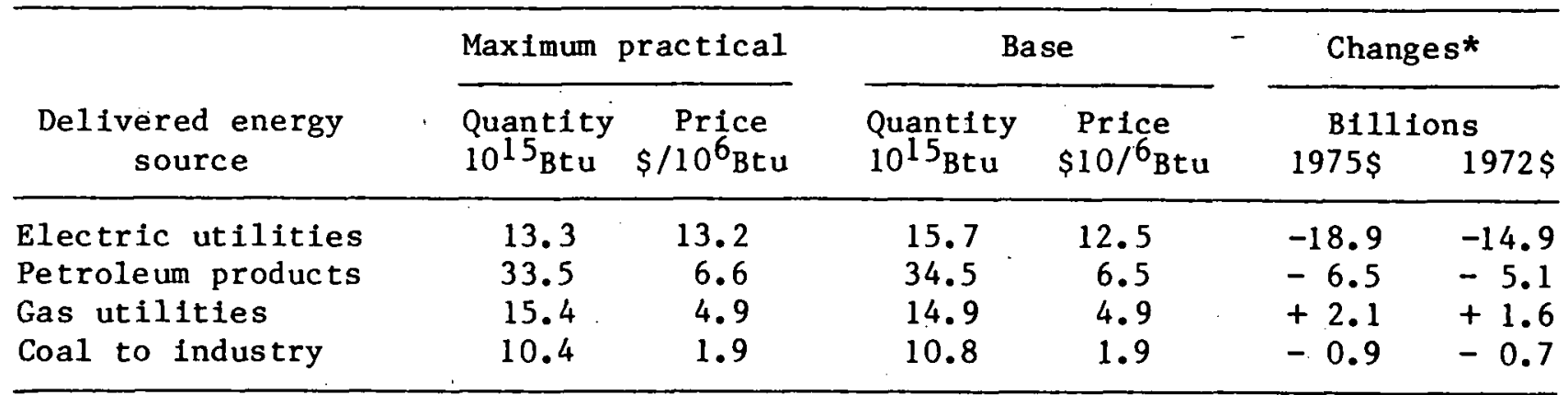

*Difference between maximum practical and base case expenditures. Source: Model runs.'

Totals may not add because of rounding.

Table 2

Economic Impact by Sector.

Subsidy and User Pays Cases Maximum Practical Implementation: Year 2000 (B1111ons of 1972 dollars)

\begin{tabular}{|c|c|c|c|c|c|c|}
\hline Sector & $\begin{array}{c}\text { Net solar } \\
\text { contributions }\end{array}$ & + & $\begin{array}{l}\text { Net convent } \\
\text { displacen }\end{array}$ & $\begin{array}{l}\text { ional } \\
\text { dents }\end{array}$ & $=$ & Net change \\
\hline $\begin{array}{l}\text { Agricullure/lloufuel } \\
\text { mining/construction } \\
\text { Manufacturing } \\
\text { Transportation } \\
\text { Service }\end{array}$ & $\begin{array}{l}+2.0 \\
+1.6 \\
+0.8 \\
+2.7\end{array}$ & ' & $\begin{array}{l}0 \\
0 \\
0 \\
0\end{array}$ & & & $\begin{array}{l}+2.0 \\
+1.6 \\
+0.8 \\
+2.7\end{array}$ \\
\hline $\begin{array}{l}\text { Coal mining } \\
\text { Crude petroleum } \\
\text { Refined petroleum } \\
\text { Electric utilities } \\
\text { Gas utilities } \\
\text { Crude gas }\end{array}$ & $\begin{array}{l}0 \\
0 \\
0 \\
\star \\
0 \\
0\end{array}$ & & $\begin{array}{l}-0.7 \\
0 \\
-5.1 \\
-14.9 \\
+1.6 \\
0\end{array}$ & & & $\begin{array}{l}-0.7 \\
0 \\
-5.1 \\
-14.9 \\
+1.6 \\
0\end{array}$ \\
\hline $\begin{array}{l}\text { Capital services } \\
\text { Labor service. }\end{array}$ & $\begin{array}{r}+34.3 \\
+\quad 1.9 \\
\end{array}$ & & $\begin{array}{l}0 \\
0 \\
\end{array}$ & $\cdot$ & & $\begin{array}{r}+34.3 \\
+1.9 \\
\end{array}$ \\
\hline Total & +43.2 & & -19.0 & & . & +24.2 \\
\hline
\end{tabular}


Table 3

Economic Impact by Sector

Competitive Case Maximum Practical Implementation: Year 2000

(Billions of 1972 dollars)

\begin{tabular}{|c|c|c|c|c|c|}
\hline Sector & $\begin{array}{c}\text { Net solar } \\
\text { contributions }\end{array}$ & + & $\begin{array}{c}\text { Net conventional } \\
\text { displacements }\end{array}$ & $=$ & Net change \\
\hline $\begin{array}{l}\text { Agriculture/nonfuel } \\
\text { mining/construction } \\
\text { Manufacturing } \\
\text { Transportation } \\
\text { Service }\end{array}$ & $\begin{array}{l}+2.0 \\
+1.6 \\
+0.8 \\
+2.7\end{array}$ & & $\begin{array}{l}0 \\
0 \\
0 \\
0\end{array}$ & & $\begin{array}{l}+2.0 \\
+1.6 \\
+0.8 \\
+2.7\end{array}$ \\
\hline $\begin{array}{l}\text { Coal mining } \\
\text { Crude petroleum } \\
\text { Refined petroleum } \\
\text { Electric utilities } \\
\text { Gas utilities } \\
\text { Crude gas }\end{array}$ & $\begin{array}{l}0 \\
0 \\
0 \\
* \\
0 \\
0\end{array}$ & & $\begin{array}{l}-0.7 \\
0 \\
-5.1 \\
-14.9 \\
+1.6 \\
0\end{array}$ & & $\begin{array}{l}-0.7 \\
0 \\
-5.1 \\
-14.9 \\
+1.6 \\
0\end{array}$ \\
\hline $\begin{array}{l}\text { Capital services } \\
\text { Labor service }\end{array}$ & $\begin{array}{r}+10.2 \\
+\quad 1.9 \\
\end{array}$ & & $\begin{array}{l}0 \\
0 \\
\end{array}$ & & $\begin{array}{r}+10.2 \\
+\quad 1.9 \\
\end{array}$ \\
\hline Total & +19.0 & & -19.0 & & 0.0 \\
\hline
\end{tabular}

Table 4

GNP and Economic Growth: Year 2000

(\$1972 Billion)

\begin{tabular}{|c|c|c|c|c|}
\hline & $\begin{array}{l}\text { Base } \\
\text { case }\end{array}$ & $\begin{array}{c}\text { Competitive } \\
\text { case }\end{array}$ & $\begin{array}{l}\text { Subsidy } \\
\text { case }\end{array}$ & $\begin{array}{c}\text { User Pays } \\
\text { case }\end{array}$ \\
\hline Gross national product & $2700 *$ & $2700 *$ & 2650 & 2630 \\
\hline Consumption & $1740^{*}$ & $1740 *$ & 1700 & 1680 \\
\hline Investment & $390 *$ & $390 *$ & $380 *$ & $380 *$ \\
\hline Government & 570 & 570 & 570 & 570 \\
\hline Net Exports & $\star \star$ & $* *$ & ** & ** \\
\hline \multicolumn{5}{|c|}{ Average annual growth of GNP } \\
\hline $1977-2000(\%)$ & 3.11 & 3.11 & 3.04 & 2.99 \\
\hline \multicolumn{5}{|c|}{$\begin{array}{l}\text { *The solution values of these quantities differed in the detailed computer } \\
\text { output for quantities of less than ten billion dollars if not rounded. } \\
\text { **ess than five billion dollars. } \\
\text { Source: Model runs. } \\
\text { Totals may not add because of rounding. }\end{array}$} \\
\hline
\end{tabular}




\section{B. Subsidy Case}

Both the absolute level of GNP and growth rate are lower in the subsidy case than in the base case because the solar technologies are less efficlent per dollar cost in providing energy than the lower cost conventional alternatives. The required labor and capital inputs per unit of energy output are increased and this reduction in productivity is reflected throughout the economy in the form of lower wages, decreased returns to capital, and a fall in output. In the subsidy case, the consumers are reimbursed for their additional energy costs and use this income for nonenergy products. This results in checking some of the GNP decline and in generating some additional energy demands to produce the additional nonenergy products.

\section{User Pays Case}

Like the suhsidy case, both GNP and its growth rate decrease relative to the base case, because there is wu inciue supplement to offoct the higher energy costs, the absolute level and the growth rate of GNP are smaller llial in the subsidy case. Most of the decrease occurs in consumption since the additional expenditures for energy must come largely from consumer expendilures.

\section{PRIMARY ENERGY CONSUMPTION}

Although the economic impact of the high cost solar technology scenarios is small (but significant), the impact on energy consumption is much more striking. Table 5 shows a considerable drop in primary energy use for all three "maximum practical" penetration cases. The differences in energy use among the three cases reflect the differences in economic activity. The solar penetration levels and the electric generation by oil, gas, and nuclear are fixed. Domestic production of oil and gas are upper bounded. This leads to the increased solar implementation of the "maximum practical" case displacing some combination of imports and coal. The pattern of displacement differs between the competilive case and the two noncompetitive cases. In the competitive case the level of economic activity is unchanged from the base case. The solar contribution largely displaces electricity which is largely produced from coal. Thus the competitive solar case shows little decrease in oil imports but a substantial decrease in coal requirements.

For the subsidy and user pays cases, the displaceinent of conventional sources by higher cost solar results in a decrease in the rate of growth and absolute level of GNP. The level of real wages is lower and the derived demand for fuel. to provide the lower level of energy services is reduced. This effect; unlike that of the solar substitution in the competitive case, generates a substantial decrease in imported oil requirements. As in the competitive case, there is a marked decrease in coal consumption as conventional electricity is displaced by the solar alternatives.

The energy GNP ratio is often used to describe energy efficiency. All three "maximum practical" cases show marked improvement in this measure, 
Table 5

Primary Energy Consumption: Year 2000

(Quadrillion Btu)

\begin{tabular}{lrcrr}
\hline & $\begin{array}{c}\text { Base } \\
\text { case }\end{array}$ & $\begin{array}{c}\text { Competitive } \\
\text { case }\end{array}$ & $\begin{array}{c}\text { Subsidy } \\
\text { case }\end{array}$ & $\begin{array}{c}\text { User pays } \\
\text { case }\end{array}$ \\
\hline Domestic oil & 19.4 & 19.4 & 19.4 & 19.4 \\
Imported oil & 16.9 & 15.8 & 12.0 & 10.0 \\
Domestic gas & 16.5 & 16.5 & 16.5 & 16.5 \\
Imported gas & 0.0 & 0.0 & 0.3 & 0.3 \\
Biomass & 0.4 & 0.8 & 0.8 & 0.8 \\
Coal & 25.5 & 14.1 & 16.7 & 16.0 \\
Solid waste & 0.3 & 0.9 & 0.9 & 0.8 \\
Wood & 2.5 & 2.9 & 2.9 & 2.9 \\
Nuclear $\quad 24.3$ & 24.3 & 24.3 & 24.3 \\
Other nonfossil electric & 8.5 & 11.2 & 11.2 & 11.2 \\
Nonfossi1 direct & 3.0 & 5.8 & 5.8 & 5.8 \\
$\quad$ Total primary energy & 117.3 & 111.7 & 110.8 & 108.0 \\
$\quad$ Energy-GNP ratio $\quad$ (103 Btu/1972\$ & & & & 41.2 \\
$\quad$ Imports share of total & 43.5 & 41.5 & 41.8 & 9.5 \\
$\quad$ primary energy (\%) & 14.4 & 14.2 & 11.1 & 4 \\
\hline
\end{tabular}

Source: Model runs.

Totals may not add due to rounding.

partially due to the displacement of electricity by solar since the conversion losses associated with conventional electricity generation are greater than those of the solar replacements, and al so to factor substitution away from higher priced energy in the subsidy and user pays cases. The small differences between the se cases are probably not significant.

The last row in Table 5 shows the powerful effect of the level of economic activity on oil consumption. We know that an effective but painful way of decreasing imported fuel requirements in the short $r$ un is to operate the economy at less than full capacity. The model results imply that a decrease in the growth rate of the ecunumy wlll generace corresponding long-run reductions in imports.

\section{EMPLOYMENT AND PRODUC'TIVITY}

\section{A. Aggregate Employment Effects}

Employment levels are virtually unchanged between scenarios. The lower real wage rates associated with the higher cost scenarios result in a decrease 
in the available labor at the equilibrium wage rate.* As shown in Table 6 , the indicated decrease in the number of jobs 1 s very small and occurs in response to the lower labor productivity under the long-run assumption that the labor market is cleared.

Inflationary effects of the higher cost scenarios are generated by the model; as expected, the model indicates an increase in the general price level al though the magnitude is very small.

\section{B. Productivity Effects}

The chief mechanism affecting model outcomes is the endogenous capture of factor substitutions in response to relative factor prices. The values of the coefficients for the year 2000 are shown in Table 6. Perhaps the most significant change is the increase in the capital coefficient for the high cost solar cases. This more capital-intensive system generates a lower not a higher income beranse the energy capital requirements per unit of energy services are higher. Historically, capital has been directed toward developing substitutes for Labor and increasing labor productivity. 'I'he model indicaces that lil all ela characterized by increasing resource cost, capital investment may be directed more to increasing resource productivity and less to Lmproving latur productivity.

The input-output coefficients change markedly between 1985 and 2000 . The base case capital coefficient increases by $13.3 \%$; 1 abor and energy coefficients decline by 12.4 and $13.9 \%$ respectively; the materials coefficient remains relatively constant showing a $1.3 \%$ increase. The difference in the temporal changes between scenarios is very small. It is clear that the model implies a much more capital-intensive economy with sharply decreased labor and energy requirements per unit of output for the year 2000 .

\section{Disaggregated Employment Effects}

The BNL input-output/linear programming model contains 110 sectors. The labor coefficients for these sectors have been projected to the year 2000. The convergent energy/economy solution provides activity levels for each sectur. The level of sectoral employment is estimated by the product of these activily levels and the projected labor coefficlents.

- Sectoral occupational-mix coefficients are then applied to the employment projections for each sector, and the change in occupational mix is calculated. These coefficients, supplied by Lawrence Berkeley Laboratory, describe the 1972 occupational skill mix. When they are applied to the 2000 activity level the employment for each skill is generated. The employment mix is based on chc working assumption that the skill mix in each sector will not change between 1972 and 2000. The change in skill mix over the whole economy is the result of the change in the structure of employment across industries and not of changes of skill mixes within industries. The results should be viewed with these caveats in mind.

\footnotetext{
This results from the supply curve for labor incorporated in the DJA model. If the long-run supply curve was backward bending, available labor might increase with lower real wages.
} 
Table 6

Employment and Productivity: Year 2000

\begin{tabular}{|c|c|c|c|c|}
\hline & $\begin{array}{l}\text { Base } \\
\text { case }\end{array}$ & $\begin{array}{l}\text { Competitive } \\
\text { case }\end{array}$ & $\begin{array}{l}\text { Subsidy } \\
\text { case }\end{array}$ & $\begin{array}{l}\text { User Pays } \\
\text { case }\end{array}$ \\
\hline Employment (millions) & 122.5 & 122.5 & 122.3 & 121.8 \\
\hline Unemployment rate $(\%)$ & 4.8 & 4.8 & 4.8 & 4.8 \\
\hline $\begin{array}{l}\text { Gross labor productivity } \\
\text { (Real GNP/employment) } \$ 10^{3} / \mathrm{MY}\end{array}$ & 22.0 & 22.0 & 21.7 & 21.6 \\
\hline \multicolumn{5}{|l|}{$\begin{array}{l}\text { Year } 2000 \text { input-output } \\
\text { coefficient for: }\end{array}$} \\
\hline $\begin{array}{l}\text { Capital } \\
\text { Labor } \\
\text { Energy } \\
\text { Materials }\end{array}$ & $\begin{array}{l}.1983 \\
.1860 \\
.0280 \\
.5877\end{array}$ & $\begin{array}{l}.1991 \\
.1862 \\
.0276 \\
.5877\end{array}$ & $\begin{array}{l}.2033 \\
.1850 \\
.0281 \\
.5836\end{array}$ & $\begin{array}{l}.2033 \\
.1851 \\
.0275 \\
.5840\end{array}$ \\
\hline
\end{tabular}

Source: Mode1 runs.

The employment response to the DPR cases for sixteen selected sectors is shown in Table 7. Employment changes in the energy sectors reflect the shift away from coal and oil showing substantial decreases in coal employment relative to the base case. Since the coal industry grows, even in the subsidy and user pays cases, there is a lower rate of growth in employment rather than a decline, and thus less economic dislocation than would result from absolute decreases in coal production. Substantial percentage increases in employment occur in the synthetic gas and combined-cycle electric sectors reflecting the large increases in output over very small bases. The employment gains in the hydroelectric sector result from the penetration of low-head hydro which does not appear in the base case.

The solar-related energy sectors show decreases in residential construction employment. The SERI data included much of the installation labor in the solar component sectors. The surprising decrease in labor requirements in residential new construction reflects this accounting convention. The increase in labor requirements in the maintenance and repair construction sector more than offsets the decline in residential construction. The plastics and synthetic materials, glass and glass products, and forestry and fisheries sectors all show substantial increases based on increased "maximum practical" scenario demands for plastics, glass, and wood.

The employment impact on nonenergy conventional fuel-related activities is quite large. The decrease in nonresidential construction results in part from the lower GNP growth rate and the associated decreased level of capital formation and in part from the decrease in new construction of facilities (e.g., refincrics). The relative decliue in employment in the public utility construction and the engines and turbines sectors derives from the decreased construction of electric generating stations. 
Table 7

Sectoral Employment Changes: Year 2000

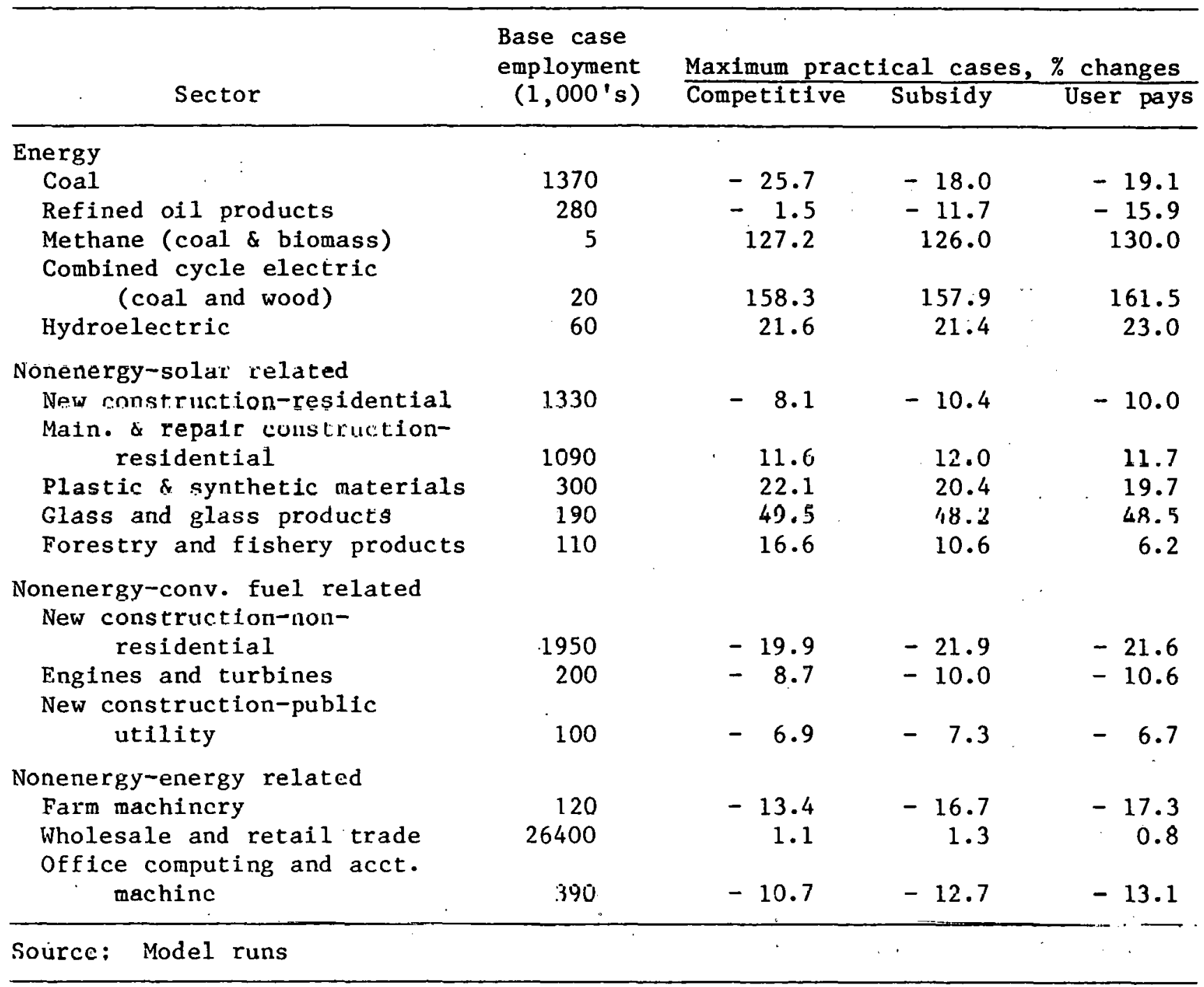

Export industries are affected by the decrease in exports resulting from the deccreased need to earn foreign exchange to flnance vil imports. The cffect of reducing traditional U.S. capital goods exports is illustrated by the engine and turbine sector as well as the office, computing, and accounting machine sector. The farm machinery sector is affected not unly by the fall in the need to export but indirectly by the decrease in agricultural exports. By and large, the capital goods secrors all shuw decreases in employmont. 
The effect on the wholesale and retail trade sector is characteristic of the service, communication, and transportation sectors. These all show small but positive increases. This shift in economic activity toward the service industries explains the effect of the "maximum practical" cases on the occupational skill mix, as shown in Table 8. The introduction of the solar technologies directly reduces the output of the conventional energy sectors, particularly electricity, and indirectly reduces the output of the manufacturing sectors supporting them. Through the reduction in exports the input requirements of the export-producing manufacturing sectors are also reduced. The released resources are partly absorbed by the solar technology industries and the remainder by the service industry sectors.

The net changes are very small and result in releasing unskilled, semiskilled, and skilled labor as well as foremen from the manufacturing sectors and in increasing professional, management, clerical, and sales employment in the service sectors. Table 9 reflects the same shifts with decreased employment in the energy, manufacturing, and construction industries arising from the shift away from manufacturing for export and the decrease in electric utility, refinery, and coal mining activities which affect construction as well as equipment. The released labor services are absorbed by the service, trade, finance, communication, transportation, and agriculture sectors. The solar data from SERI that allocated much of the solar construction to the solar supply sectors reinforces the construction employment loss due to the decrease in utility and manufacturing activity.

Table 8

Comparison of the Occupational Structure of Total Industrial Employment

Year 2000 Cases

\begin{tabular}{|c|c|c|c|c|}
\hline \multirow[b]{2}{*}{ Occupational class } & \multirow[b]{2}{*}{ Base ; \% } & \multicolumn{3}{|c|}{ Maximum practical, $\%$} \\
\hline & & Competitive & Subsidy & User pays \\
\hline Engineers \& scientists & 1.82 & 1.81 & 1.81 & 1.82 \\
\hline Other professionals & 9.77 & 9.85 & 9.86 & 9.86 \\
\hline Management, clerical, sale & 37.95 & 38.33 & 38.33 & 38.32 \\
\hline Foreman & 1.88 & 1.85 & 1.85 & 1.85 \\
\hline Skilled labor & 12.63 & 12.18 & 12.29 & 12.33 \\
\hline Semiskilled labor & 28.95 & 28.94 & 28.94 & 28.91 \\
\hline Laborers & 6.99 & 6.94 & 6.92 & 6.91 \\
\hline Totals & 100.00 & 100.00 & 100.00 & 100.00 \\
\hline
\end{tabular}

Sollre: Model runs. 
Table 9

Comparison of the

Industrial Structure of Total Industrial Employment Year 2000 Cases

\begin{tabular}{|c|c|c|c|c|}
\hline \multirow[b]{2}{*}{ Industry } & \multirow{2}{*}{ Base,\% } & \multicolumn{3}{|c|}{ Maximum Practica1, \% } \\
\hline & & Competitive & Subsidy & User pays \\
\hline Energy & 4.39 & 4.02 & 4.14 & 4.16 \\
\hline Agriculture & 2.20 & 2.23 & 2.22 & 2.20 \\
\hline Nonfuel mining & 0.35 & 0.37 & 0.36 & 0.36 \\
\hline Construction & 7.10 & 6.60 & 6.60 & 6.66 \\
\hline Manufacturing & 22.58 & 22.52 & 22.37 & 22.32 \\
\hline Transportation & 2.28 & 2.32 & 2.30 & 2.29 \\
\hline Communicatinns & 1.08 & 1.09 & 1.09 & 1.09 \\
\hline 'I'rade & 25.74 & 26.10 & 26.11 & 26.12 \\
\hline Finance, insurance + & & & & \\
\hline real estate & 6.49 & $6.7: 1$ & 6.71 & 6.71 \\
\hline Services & 27.78 & 28.05 & 28.10 & 28.07 \\
\hline Total & 100.00 & 100.00 & 100.00 & 100.00 \\
\hline
\end{tabular}

Source: Model runs.

\section{ENVIRONMENTAL IMPACTS}

The combined model system generates the emission streams associated with the optimum (least cost) energy, long-run economic equilibrium solution. These are presented in Table 10. It is clear that all of the "maximum penetration" scenarios lead to substantially reduced emission streams. Most air quality emissions are reduced by about 20 to $25 \%$ except for heat and for hydrocarbons, carbon monoxide, and aldehydes in the compelitive case. The reduction results from the substitution of solar lur coal in all scenarios and the reduced use of oil because of lower economic growth in the high cost scenarios. Without information on the location of the emitters and of the population, both virtually impossible to assess with any degree of confidence for the year 2000, little can be said about health and other effects. Ilowever, emission-creating activity and population are correlared so that: the assumption that health and other effects are greater if enissions are greater is not wholly unreasonable.

Much the same picture appears for water related emissions with a decrease of ahnut. 50\% for the "maximum practical" cases. Land use for energy purposes is decreased by 15 t.o $20 \%$ and direct occupational satety measures show decreases of 30 to 40 percent. 'lhe subsidy and user pays cases show a sualler reduction in occupational safety than the competitive case because coal consumption falls less and coal production, transportation, distribution, and consumption contribute heavily to the occupational safety totals. 


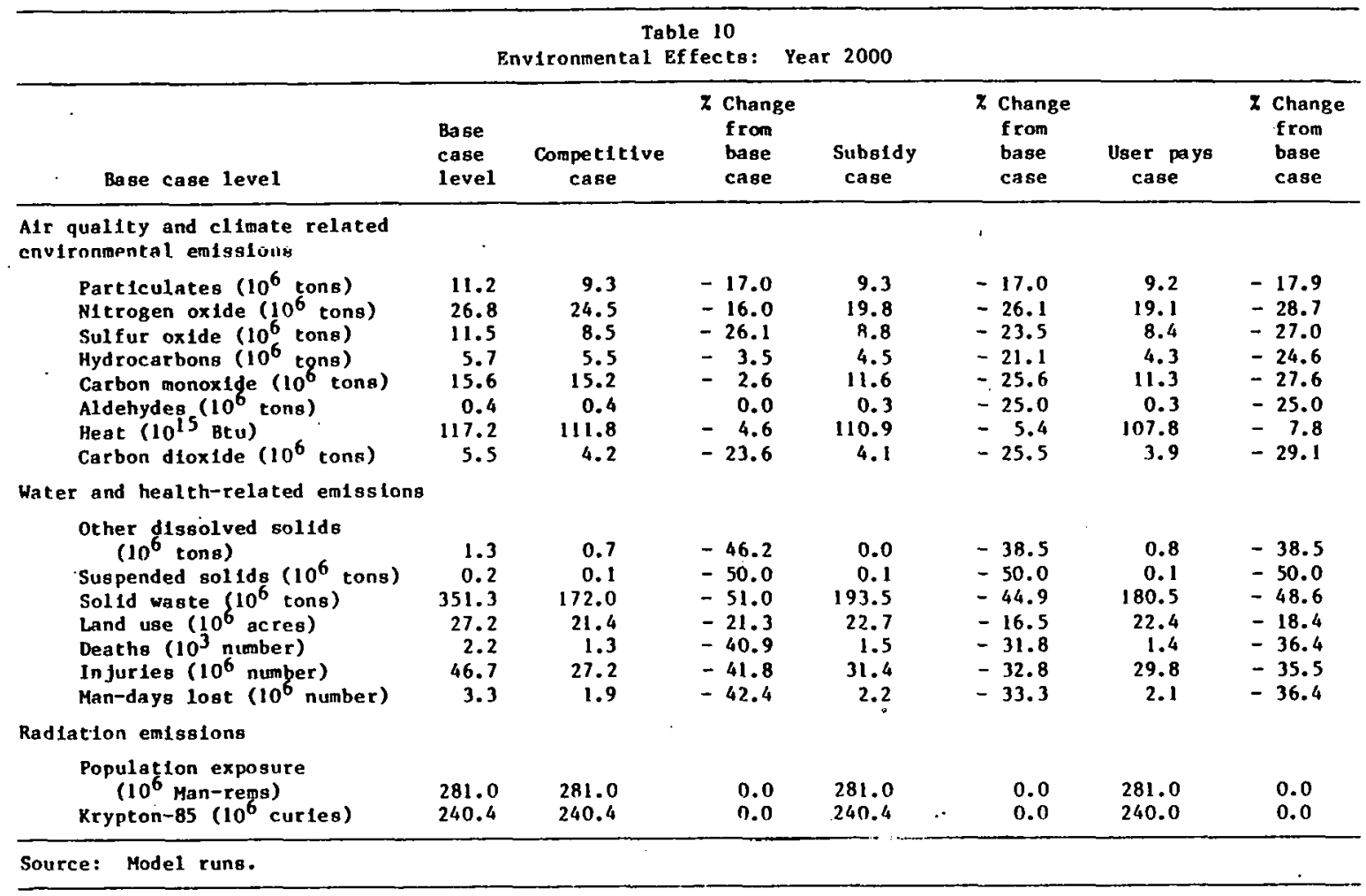

VIII. CONCLUSION

This paper discusses a study in the context of the real life constraints under which policy analysts operate. The results are significant in that they are counter to the conventional wisdom that solar technologies create employment and shift the occupational mix toward blue collar jobs. They also indicate that increased capital intensity in the future may not lead to increased labor productivity. The results imply that the differences in the time paths of capital expenditure between solar and conventional energy technologies, even if they are equal in cost, are an area for worthwhile research. The assumption used in this study was that life-cycle costs are equal. The case of equal capital costs has not yet been investigated.

These findings are musual. They are heavily dependent on two characteristics of the modeling structure. First, the international trade balance mechanism assumes that exports fall in response to lower fuel imports and that these exports have the same sectoral composition in 2000 as in the recent past. Second, the econometric formulations reflect the increasing fraction of output arising from tertiary industries that has been true historically and assumes that this trend continues through 2000. 
Market Penetration of Solar Technologles: 2000 (10 $15 \mathrm{Btu}$ of 011 Equivalent Displaced)

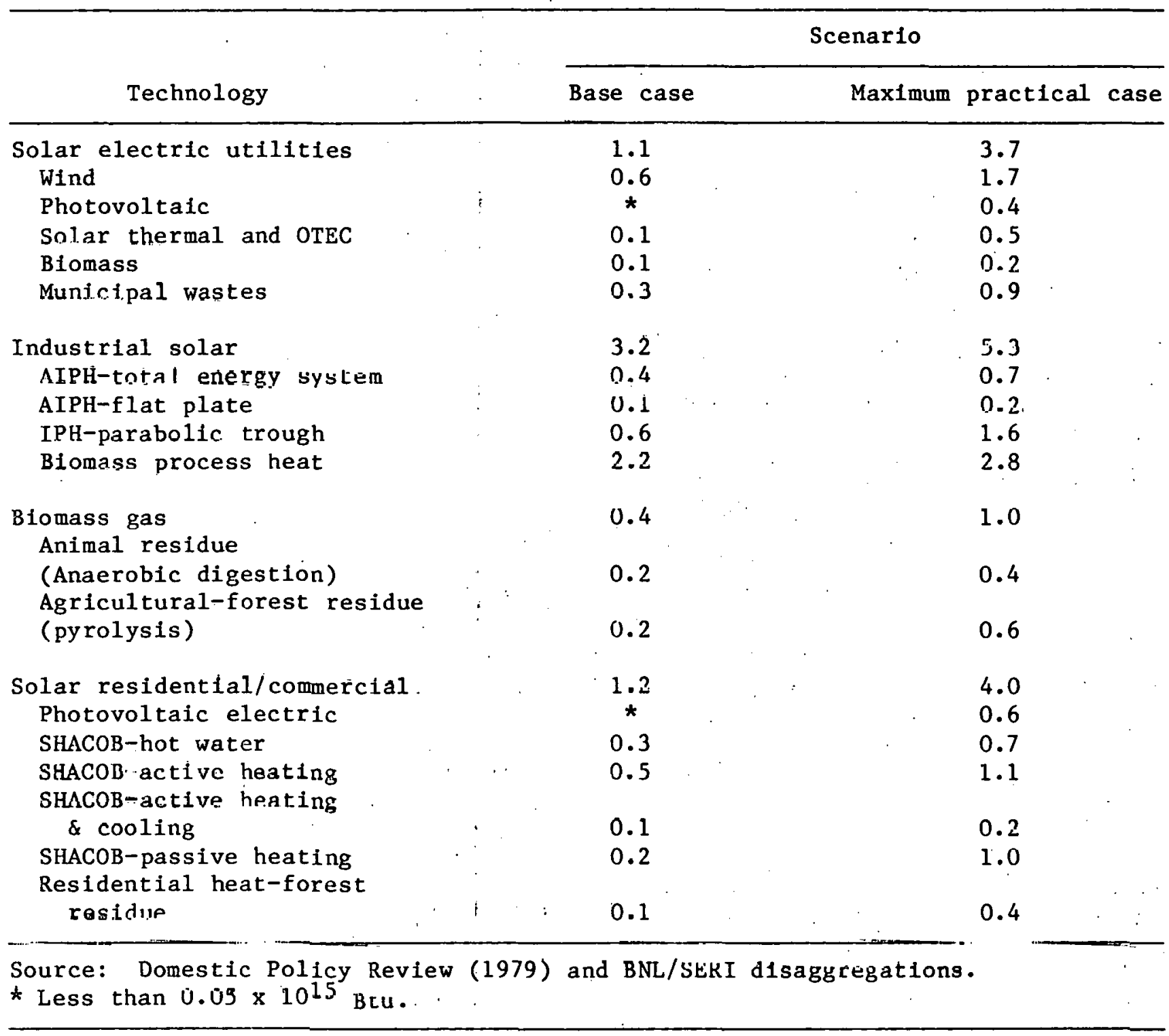




\section{REFERENCES}

1. Behling, D.J., W. Marcuse, J. Lukachinski, and R. Dullien, The long term consequences of phasing out nuclear electricity, in C.J. Hitch, Ed., Modeling Energy-Economy Interactions: Five Approaches, Resources for the Future, Washington, DC, 1977.

2. Charles River Associates, Review and Evaluation of Selected Large Scale Models, prepared for the Electric Power Research Institute, Charles River Associates, Cambridge, MA, 1977.

3. Cherniavsky, E.A., Brookhaven Energy System Optimization Model, BNL 19569, 1974 .

4. Domestic Policy Review of Solar Energy, U.S. Department of Energy, February 1979 .

5. Energy Policy Project of the Ford Foundation, A Time To Choose, Ballinger, Cambridge, MA, 1974.

6. Fraser, J.T., Documentation of the Brookhaven Energy I-O and I-O BESOM Linkage, BNL 50856, 1978 .

7. Groncki, P.J., A General Equilibrium Approach to Energy/Environmental Economic Analysis, BNL 24781, August 1978 .

8. Groncki, P.J. and W. Marcuse, The Brookhaven Energy/Economy Modeling System and its Use in Conservation Policy Analysis, BNL 51056, 1979.

9. Hoffman, K.C. and D.W. Jorgenson, Economic and technological models for evaluation of energy policy, Bell J. Econ., Vol. 8, No. 5, pp. 444-466 (Autumn 1977).

10. Jorgenson, D.W. and E.A. Hudson, U.S. energy policy and economic growth, Bell J. Econ. Manage. Sci., Vol. 5, No. 2, pp. 561-514 (Autumn 1974).

11. Just, J., B. Borko, W. Parker, and A. Ashmore, New Technology Coefficlents and Dynamic Energy Models, 2 Vol. prepared by the MITRE Corporation for the Energy Research and Development Administration, ERDA-3, Washington, DC, 1975.

1.2. Kydes, A.S., The Brookhaven Energy Systems Optimization Model, Its Variants and Uses, BNL 50873, 1978.

13. Kydes, A.S. and J. Rabinowitz, The Time-stepped Energy System Optimization Model: (TESOM) Overview and Special Features, BNL 26456, August 1979.

14. Lukachinski, J., P.J. Groncki, R.G. Tessmer, Jr., R.J. Goettle IV, and F.A. Hudson, An Integrated Methodolugy for Assessing Energy-Economy Interactions, BNL 26452, 1979.

15. Tessmer, R.G., K.C. Hoffman, W. Marcuse, and D.J. Behling, Coupled Energy System-Economic Models and Strategic Planning, BNL 20120, 1975. 